\title{
Researching Entrepreneurial Failures
}

\section{INTRODUCTION}

Due to the highly uncertain nature of pursuing new business opportunities (Knight, 1992; McMullen \& Shepherd, 2006), failure is a rather common outcome of entrepreneurial endeavors (Brüderl, Preisendörfer, \& Ziegler, 1992; Shane, 2009; Wiklund, Baker, \& Shepherd, 2010). Take family businesses as an example. They comprise a significant share of all businesses (up to $90 \%$ in the USA [Dumas, 1992; Heck \& Trent, 1999; Kets de Vries, 1993]), but nearly $70 \%$ of family businesses fail to make it through the second generation, and roughly $90 \%$ fail to survive through the third generation (Kets de Vries, 1993). Similarly, established firms often undertake entrepreneurial projects as part of corporate entrepreneurship initiatives to create new products, enter new markets, explore new technologies, and/ or build new businesses (Zahra, Jennings, \& Kuratko, 1999). Like businesses, however, entrepreneurial projects are basically experiments with unknowable outcomes; there is an air of uncertainty (McGrath, 1999). Thus, sporadic or even repeated entrepreneurial project failure is an inevitability in firms practicing corporate entrepreneurship (Burgelman \& Välikangas, 2005). In fact, Boulding, Morgan, \& Staelin (1997) estimated that $35-45 \%$ of all new products fail (Boulding, Morgan, \& Staelin, 1997).

In this chapter, we build on Shepherd, Covin, and Kuratko (2009); Shepherd (2009); and Ucbasaran, Shepherd, Lockett, and Lyons (2013).

D.A. Shepherd, H. Patzelt, Trailblazing in Entrepreneurship, DOI 10.1007/978-3-319-48701-4_3 
Further, investigating 95 venturing units in corporations with headquarters in eight countries worldwide, Campbell, Birkinshaw, Morrison, and van Basten Batenburg (2003) reported no successful examples among firms exploring "new leg" ventures or among internal corporate ventures started with the sole purpose of pursuing growth opportunities in novel (to the firm) product-market domains.

While being able to successfully exploit entrepreneurial opportunities is the primary aim of all entrepreneurship initiatives, failure is not necessarily a completely negative outcome as some failures can lay the foundation for subsequent success. This path from failure to success has been seen in new product development (Maidique \& Zirger, 1985), internal corporate venturing (McGrath, 1995), and joint venturing (Peng \& Shenkar, 2002). Although some failures lead to positive outcomes, success is by no means a certain consequence of failure. For success to follow failure, it is essential for the entrepreneur or the organization to learn from past mistakes. As such, entrepreneurial failures can actually be potential learning opportunities (Green, Welsh, \& Dehler, 2003). By signaling a problem with one's current beliefs or actions (Chuang \& Baum, 2003; Sitkin, 1992), failure can motivate individuals to look for solutions (Ginsberg, 1988; McGrath, 2001; Morrison, 2002; Petroski, 1985). Furthermore, failure often triggers sensemaking efforts, thereby serving as a rich source of information for learning. Thus, learning from failure refers to "the sense that one is acquiring, and can apply, knowledge and skills" (Spreitzer, Sutcliffe, Dutton, Sonenshein, \& Grant, 2005, p. 538) as a direct result of a failure experience. When entrepreneurs take chances, learn from their failures, and act on the new knowledge they gain from those failures, economies are able to progress (Hoetker \& Agarwal, 2007; Knott \& Posen, 2005; Mason \& Harrison, 2006). Moreover, when entrepreneurs and organizations gain new knowledge from their failures, they are more likely to become involved in future entrepreneurial initiatives (Hayek, 1945). Such initiatives can serve as possible foundations for firm growth and renewal (McGrath, Tsai, Venkataraman, \& MacMillan, 1996), thus increasing individuals' odds of succeeding with a new venture after a failure. In a similar way, those who failed in a corporate setting can aid their organizations in improving their innovation "hit rate" by learning from their failures and emotionally committing to later projects.

Because failure can motivate individuals to gain new knowledge or skills, researchers argue that people tend to learn more from their failures than from their successes (Petroski, 1985; Popper, 1959). Sitkin (1992, p. 243) 
suggested that learning from failure is most likely to occur when failure events "(1) result from thoughtfully planned actions, (2) have uncertain outcomes, (3) are of modest scale, (4) are executed and responded to with alacrity, and (5) take place in domains that are familiar enough to permit effective learning." However, alacrity-namely, "brisk and cheerful readiness" (Concise Oxford Dictionary) — is difficult to maintain when the failure means that the entrepreneur loses something that is important to him or her (i.e., a project or a business). Although most organizations and their members believe that learning from failure is important, they generally find doing so to be difficult (Cannon \& Edmondson, 2005), as do entrepreneurs who lose their business (Byrne \& Shepherd, 2015; Shepherd, 2003). More specifically, while failure reveals important information, organizations and individuals are frequently unsuccessful at fully processing that information (Weick, 1990; Weick \& Sutcliffe, 2006). We need to gain a deeper understanding of the costs of failure (project and business) to the entrepreneur (and by extension the organization) and the ways these costs of failure can create obstacles to achieving the benefits of failure-namely, learning from the experience. However, before we delve into the nuances of advancing knowledge on this important topic, it is important to start with what we mean by failure (in its various forms).

\section{Defining Entrepreneurial FaIlures}

Failure has been conceptualized in a number of ways, including as the discontinuity of ownership (for a review, see Singh, Corner, \& Pavlovich, 2007), bankruptcy (e.g., Shepherd \& Haynie, 2011), and discontinuity caused either by insolvency (Coelho \& McClure, 2005; Shepherd, 2003) or by performance below the decision makers' threshold (e.g., Ucbasaran, Westhead, Wright, \& Flores, 2010). Indeed, Ucbasaran et al. (2013, p. 175) defined business failure as "the cessation of involvement in a venture because it has not met a minimum threshold for economic viability as stipulated by the (founding) entrepreneur." Shepherd and colleagues defined project failure as the termination of an initiative to create organizational value that has fallen short of its goals (Shepherd, Covin, et al., 2009; Shepherd, Patzelt, \& Wolfe, 2011; see also Hoang \& Rothaermel, 2005; McGrath, 1999). While there are numerous definitions of failure, we believe researchers should utilize the definition that best fits their study's research question. Nevertheless, it is important that the authors offer a clear, explicit definition and a justification for its use. We organize the rest 
of this chapter based on the major implications arising from the failure of projects or businesses-implications that are financial, social, emotional, or a combination of these implications - and offer various future research opportunities.

\section{The Financial Implications of Entrepreneurial FAILURE}

The literature captures a long history of scholars focusing on the financial costs of failure. For example, an entrepreneur must often take on personal debt to fund his or her business, which he or she must then bear after business failure (Cope, 2011). However, it appears that the financial costs of failure (project and/or business) for the individual depend on the culture and the broader institutions in which the individual is embedded. For example, bankruptcy laws vary by country, and the "strictness" of these laws has a bearing on the financial costs borne by the entrepreneur from a failed business (Lee, Peng, \& Barney, 2007; Lee, Yamakawa, Peng, \& Barney, 2011). Although we have gained a substantial understanding of the financial costs of failure (and, for that matter, the financial costs of persisting despite poor performance [Gimeno, Folta, Cooper, \& Woo, 1997; Shepherd, Wiklund, \& Haynie, 2009]), there is still much to learn.

Recovering from the financial costs of entrepreneurial failure. First, we believe it is necessary to gain deeper insights into how and why some entrepreneurs are able to bounce back from the financial consequences of failure more quickly than others. What actions do such individuals take after a bankruptcy, for example, that help them deal with the financial burden? Moreover, the notion of recovery may be too limiting because it could imply that individuals merely "overcome" the financial costs of failure but does not take into account the possible financial benefits of failure over time. For instance, ultimate financial success after business failure may require individuals to take on traditional employment for a period to restore their financial reserves before entering into business ownership again. Further, those who suffer considerable financial loss after business failure are likely to learn significant lessons in how to manage their subsequent venture's financial resources. What lessons are learned in these difficult contexts, and how do they affect the business model and capital structure of subsequent ventures? Future research can investigate these entrepreneurial career paths (i.e., the sequence of entrepreneurs' career 
decisions) to help elucidate how entrepreneurs recover from the financial consequences of business failure and capitalize on the benefits of failure to attain financial success in the long term.

Even less clear are the financial costs of project failure within an organization. How does project failure impact the career trajectory of a member of a failed team effort? In some organizations, management may view the leaders of a failed project as lacking leadership, competence, and persistence, which likely obstructs a productive career path for the corporate entrepreneur. In response, the entrepreneur is likely to either leave the organization or stay with the organization but limit entrepreneurial activity (and other organizational members are likely to learn the same behavior vicariously). With either response from the (former) corporate entrepreneur, the organization loses because it kills (or substantially diminishes) the entrepreneurial spirit of the firm. In contrast, there are organizations that are more tolerant of failure and even some that celebrate it. How does a project failure impact the career trajectory of a corporate entrepreneur in such an organization (Farson \& Keyes, 2006), especially in contrast to organizations that penalize those associated with a project failure? Perhaps the impact of failure on career trajectory depends on what type of failure occurred, whether the individual learned from the failure, and how that learning can be applied to benefit the organization.

Entrepreneurial failure and opportunity costs. Regardless of the direct financial cost of failure (independent or corporate entrepreneur), the failure of a project or a business may lead to the termination of a (insufficiently profitable) track but may also reveal other more profitable entrepreneurial opportunities. More can be done to try to explain how the continued pursuit of one potential opportunity (e.g., persisting with a losing course of action) has an "opportunity" opportunity cost. It could be that the opportunity costs are financial. For example, because the entrepreneur is investing resources (e.g., money) into the current venture, he or she is unable to pursue another potential opportunity. However, the opportunity costs could also be attentional. When focusing attention on the exploitation of a focal potential opportunity, for instance, the entrepreneur may have insufficient attention to notice and/or interpret signals of an alternate potential opportunity. Although these financial and/or attentional constraints could help determine the nature of the opportunity cost, it is important to understand how some are able to reduce these constraints and thus reduce the opportunity costs. This may involve making small investments and rapid terminations (Bakker \& Shepherd, 2017; 
McGrath, 1999), using a conscious strategy to maintain slack (i.e., cognitive, financial, and time) resources not allocated to the current entrepreneurial endeavor (Bradley, Wiklund, \& Shepherd, 2011; George, 2005), and using other means for structuring and/or "freeing up" attentional resources (Ocasio, 1997; Shepherd, McMullen, \& Ocasio, 2017).

Financial costs of entrepreneurial failure at the group level of analysis. Not only does the entrepreneur take on the financial costs of business failure, his or her family is also likely to feel the consequences. As such, future research on entrepreneurs embedded within a family is likely to provide a more complete picture of the financial costs of business failure for entrepreneurs. For example, while two entrepreneurs may experience the same immediate financial costs after business failure, heterogeneity in each entrepreneur's family wealth may lead to different long-term financial implications. Similarly, the costs of a project failure can more easily be borne by a wealthier organization than a poorer one. How does the wealth of the actor embedded in his or her family or organization influence the nature of the financial costs, the decision to start and to terminate the entrepreneurial endeavor, and the ability and willingness to move on to the next entrepreneurial endeavor? For example, on the surface, it appears that the financial costs of failure will be less damaging to entrepreneurs belonging to wealthier groups (e.g., a corporate entrepreneur embedded in a wealthier organization or an independent entrepreneur embedded in a wealthier family); however, those who belong to less wealthy groups may tend to engage in riskier behavior overall (e.g., believe they are in a loss situation and thus act in ways in line with prospect theory), thus making them more likely to engage in subsequent entrepreneurial actions. Future research can investigate whether those with less family wealth "behind" their entrepreneurial endeavors are more likely to approach a potential opportunity with real options reasoning (for real options reasoning, see McGrath, 1999; McGrath \& Nerkar, 2004), have a fundamentally different approach to removing doubt about a potential opportunity and/or exploiting it, or are more willing to "gamble" it all with a "big bet."

Financial losses from entrepreneurial failure and subsequent entrepreneurial action. In line with research demonstrating the importance of financial slack for funding both the experimentation needed for successful entrepreneurship (see George, 2005) and start-up costs/early-stage growth (Gilbert, McDougall, \& Audretsch, 2006), it may seem like the financial costs of business failure would be a significant barrier to later entrepreneurial activity, especially in the short term. However, the resulting 
resource scarcity after business failure could create an environment that fosters bricolage (i.e., "making do with whatever is at hand" [Baker \& Nelson, 2005, p. 330]), particularly for entrepreneurs in more resourcepoor contexts and/or corporate entrepreneurs who find it more difficult to garner resources from management after failure. That is, resource scarcity can trigger entrepreneurial activity, thereby transforming an initial financial cost into a different form of resource advantage (i.e., a valuable resource combination). Are some more able to switch from entrepreneurial activity spurred by slack resources to entrepreneurial activity spurred by resource scarcity? What mechanisms enable people to switch between these two different "sources" of entrepreneurial activity? The answers to these questions likely relate to the mindset triggered (or applied) to the adversity inherent in a resource-scarce environment.

Although we may be first drawn to prospect theory (Kahneman \& Tversky, 1979) for answers, there are some other interesting possibilities. For some, this type of adversity likely generates an emphasis on resource protection-a reactive posture that involves consuming some resources to stop further resources from being lost. However, for others, this adversity could lead to an emphasis on resource investment-a proactive posture to replenish and grow resources (Hobfoll, 2001; Hobfoll \& Lilly, 1993). Williams and Shepherd (2016) showed that those who engage in resource investment in the form of entrepreneurial action (i.e., the creation of a venture to alleviate the suffering of others in the aftermath of a natural disaster) have superior functioning in that adverse environment than those who do not engage in entrepreneurial action (controlling for a host of factors). Therefore, it may not be whether one fails or how much adversity one experiences when he or she fails; the ultimate net costs (or benefits) of failure may be determined by the mindset one develops regarding whether to protect remaining resources (through conservative action) or to invest those resources in entrepreneurial activity. Shepherd and Williams (2017) also proposed that regulatory focus theory is critical in explaining who escapes an adverse situation by constructing a new work identity (i.e., those with a promotion focus) and who languishes (i.e., those with a prevention focus). As we gain a deeper understanding of how different mindsets influence individuals' reactions, responses, and recovery from failure, attention needs to turn to the antecedents of these mindsets. For example, why do some invest resources under adversity while others protect their remaining resources, and why do some who hit rock bottom after entrepreneurial failure approach the situation with a promotion focus and 
others with a prevention focus? We need to gain a deeper understanding of the mindsets that reflect the different paths and trajectories of recovery and resilience.

Entrepreneurial failure and careers. Since failure can cause an entrepreneur personal financial hardship, end his or her source of income, harm his or her professional reputation, and result in negative financial outcomes for his or her family and/or firm, it is an extreme context that enables researchers to investigate career paths so as to survey the limits of and thus advance theories on careers to reveal the long-term financial implications of failure. This type of research can contribute to and extend current theories by heeding calls for more studies on career constraints (Arnold \& Cohen, 2008) and on the ways individuals adapt to new careers (Savickas, 2002), especially when their prior career path has ended (Haynie \& Shepherd, 2011; Shepherd \& Williams, 2017) and they have financial burdens. As we hinted at earlier, we also suggest that the context of failure (of a project or a business) is ideal for extending theories of bricolage because it involves significant resource scarcity (because of failure's financial costs). Both theories may be further advanced if future research investigates how entrepreneurs who experience failure engage in bricolage to open up new career opportunities. Perhaps by cobbling together different career paths (or elements within those careers), the individual can combine and recombine various work-related aspects in ways that create a new career opportunity.

\section{The Social Implications of Entrepreneurial Failure}

Although failure can have positive consequences for the individual (e.g., learning and personal growth [Cope, 2011; McGrath, 1999; Shepherd, 2003]), others often do not see entrepreneurial failure in such an optimistic light (D'Aveni, 1990; Semadeni, Cannella, Fraser, and Lee, 2008; Sutton \& Callahan, 1987). As noted by March and Shapira (1987, p. 1413), "society values risk taking, but not gambling, and what is meant by gambling is risk taking that turns out badly." Oftentimes, the devastation of a business failure on others (e.g., former employees, suppliers, and other stakeholders) is highly salient and immediate, whereas the learning benefits (for the individual and the economy) are more diffuse and take time to develop.

Indeed, there are many reports of entrepreneurs of failed businesses being judged harshly by others. For example, historically, individuals who 
went bankrupt were subject to punishments that included "forfeiture of all property, relinquishment of spousal consortium, revocation of citizenship, surrendering children as slaves, prohibition from holding public office, imprisonment, and death"; they were required to "bang their buttocks on a rock before a heckling crowd," "wear distinguishing clothes in public," and were subject to other means of degradation and humiliation in public (Efrat, 2006, p. 366). Modern-day equivalents of others' responses to failed (or failing) entrepreneurs include rejection, avoidance, disengagement, and denigration (D'Aveni, 1990; Sutton \& Callahan, 1987). These harsh judgments place considerable blame (Semadeni, Cannella, Fraser, \& Lee, 2008; Sutton \& Callahan, 1987) for the failure on the individual, and they suggest that the entrepreneur should be punished (Efrat, 2005; Lee et al., 2007) and feel shame (Probst \& Raisch, 2005; Wiesenfeld, Wurthmann, \& Hambrick, 2008). To a greater or lesser extent, these judgments on business failure are reflected in countries' bankruptcy laws (Lee et al., 2011; Lee, Peng, \& Barney, 2007), and these judgments on project failure are reflected in an organization's culture (Cannon \& Edmondson, 2001; Tucker \& Edmondson, 2003). Such harsh judgments and the stress they generate can negatively impact the economic (Semadeni et al., 2008; Sutton \& Callahan, 1987), psychological (Byrne \& Shepherd, 2015; Shepherd, 2003), and physical (Cope, 2011; Whyley, 1998) well-being of the individual who experiences the failure. We believe that the current literature on this topic has only scratched the surface when it comes to exploring the social costs of business failure for entrepreneurs.

Relationship ties after entrepreneurial failure. While we have a strong understanding of relationship ties and the ways they affect entrepreneurial activity within (Kelley, Peters, \& O'Connor, 2009; Stam \& Elfring, 2008) and outside (Hoang \& Antoncic, 2003; Jack, 2005) the organization, we know relatively little about how these ties change (if at all) after failure. Future research has the chance to add to the body of knowledge on this topic by investigating how entrepreneurs' formal (business) relationships change after inter-organizational relationships cease as a result of business failure and when intra-organizational relationships cease due to project failure. Does failure damage these relationships beyond repair, or can they be restored? If these relationship ties are salvageable, what are the mechanisms for rebuilding a relationship tie (or conserving it through the failure) as opposed to creating a new tie? Indeed, the question becomes whether the entrepreneur is better off investing his or her time in rebuilding relationships damaged by failure or creating new relationship ties (i.e., 
relationships without baggage). How much can entrepreneurs who have experienced failure rely on past relationships to help in the recovery process and/or to provide resources for later entrepreneurial activity? How do the entrepreneur's and others' attributions of the failure impact these relationship ties?

Perhaps external attributions of failure help reduce the number of lost ties, but internal attributions of failure strengthen existing ties. Although the benefits of weak ties are lauded in the literature for their role in the identification of a potential opportunity (Ardichvili, Cardozo, \& Ray, 2003; Hoang \& Antoncic, 2003), perhaps strong ties are more important in helping reduce the social costs of failure. It could be that strong ties represent surrogates that help repair weak ties damaged by failure or help in the creation of new weak ties necessitated by the loss of previous weak ties through failure. Not only are some ties likely to be damaged and lost as the result of failure, but it could be that some ties change in nature after failure. For example, a failure may serve to strengthen the entrepreneur's relationship with a weak tie (i.e., a weak tie changes to a strong tie) and weaken his or her relationship with a previously strong tie (i.e., a strong tie becomes a weak tie). There are numerous opportunities for future research to explore the termination, use, rebuilding, re-activation, and transformation of relationship ties after a failure.

Entrepreneurial failure and social stigma. While we understand how entrepreneurs tend to handle stigmatizing situations (Sutton \& Callahan, 1987), we know less about when and why project and business failure represents a stigmatizing event. Beyond entrepreneurs' impressionmanagement strategies, do particular forms of failure and/or types of entrepreneurs cause greater stigma? For instance, Shepherd and Patzelt (2015) found that entrepreneurs who are homosexual are likely to be stigmatized more from business failure than those who are heterosexual (in one region of Germany) and that those who are trying to preserve the environment are stigmatized less for business failure than those who were not trying to preserve the environment. Perhaps female entrepreneurs in supposed "masculine" industries (or masculine organizations or roles) face more stigmatization from failure compared to women in "feminine" industries (or organizations or roles) or men in "masculine" industries (or organizations or roles). That is, when individuals deviate from the norm and fail, they may face greater social costs compared to more "normal failures." If this is the case, however, there is a societal influence that deters the type of novelty that can be highly transformative. What is the 
impact of stigma for entrepreneurial failures? Perhaps a high stigma for entrepreneurial failure stops some individuals from engaging in entrepreneurial action (as a type of fear of failure), from engaging in certain types of entrepreneurial projects or businesses (i.e., those for which the stigma from failure is the greatest), from terminating a poorly performing project or business (delaying the social costs of failure but increasing the financial costs of failure when it arrives), and/or jumping ship from a failing business in the hope of avoiding stigma. Each alternative represents a host of considerations and implications.

Entrepreneurial failure role models. While we have some knowledge on how successful entrepreneurs are viewed and serve as role models (Bosma, Hessels, Schutjens, Van Praag, \& Verheul, 2012; Krueger \& Brazeal, 1994), we can still learn more about the social signals sent and received from entrepreneurs' business failures. For instance, on the one hand, parents who have entrepreneurial success often serve as role models for their children, not only showing them that entrepreneurship is an achievable and desirable career path but also encouraging their children's entrepreneurial goals and actions (Davidsson \& Honig, 2003). On the other hand, how does a parent's business failure influence the "next generation" of potential entrepreneurs? Children who observe and experience (either directly or indirectly) the negative effects of business failure may decide to forgo entrepreneurial careers because they view business failure as a highly prominent possible outcome of entrepreneurial action. However, parents' ability to "bounce back" after failure and show resilience could decrease their children's fear of failure, thereby helping them form more positive beliefs about failure (for initial evidence, see Politis \& Gabrielsson, 2009). Perhaps parents who had a business fail (or a mentor who had a project fail) serve as excellent role models for how to face failure, deal with it, recover, learn, and-ultimately-move forward. That is, maybe people can learn how to cope with and benefit from failure vicariously. If this is the case, increases in the saliency of entrepreneurial failure (perhaps through coping self-efficacy or some other mechanism) may make entrepreneurial action more-rather than less-likely.

The role of social skills in dealing with entrepreneurial failure. We believe it is valuable to explore the role social skills play in entrepreneurs' responses to failure, including social perception, expressiveness, impression management, and social adaptability. Baron and Tang (2009) highlighted a number of studies establishing the impact these skills have on important outcomes in numerous contexts, including entrepreneurial contexts. 
Individuals with strong social skills are likely to be highly skilled at reducing the social costs of business failure (e.g., through shrewd storytelling and sensegiving to others regarding the failure and the role they played in that failure) as well as the associated psychological costs. Additionally, individuals with strong social skills often have wider and more diverse social networks (Diener \& Seligman, 2002) with which they can connect to talk about a failure and receive support. Future research can investigate the role social skills play in how entrepreneurs manage the social and psychological costs (and, indirectly, the financial costs, as discussed above) of failure.

There is also an opportunity to gain a deeper understanding of the impact of failure through a fine-grained understanding of an entrepreneur's (corporate or independent) social skills. Which of the social skills-social perception, expressiveness, impression management, and social adaptability-influence which aspect of the failure-resilience/failure-recovery process and to what effect? For example, expressiveness may facilitate a loss orientation, and a loss orientation might help reduce the social costs of the failure as the individual is able to express his or her negative emotions over the failure. However, it appears that having a loss orientation for an extended period can exacerbate negative psychological reactions to the failure (see Shepherd et al., 2011). Therefore, it might not be that greater social skills necessarily lead to better outcomes-there could be tradeoffs, diminishing returns, and even negative returns at high levels. To the extent that there are tradeoffs between different outcomes of a particular social skill, can the downside of that particular social skill be overcome or offset by the activation of a different social skill? It is important to gain a deeper understanding of not only the different social skills and their differential effects on failure outcomes but also the ways these social skills can be combined to reduce the overall costs of failure. With this deeper understanding, we hope that scholars are in a better position to teach students and budding entrepreneurs (whether corporate or independent) the social skills that not only help them succeed with their projects and their businesses but also deal with the possibility (and even the probability) that their entrepreneurial endeavors (projects or businesses) will fail.

Entrepreneurial failure and work-life balance. While research has explored work-life balance among entrepreneurs (Shepherd \& Haynie, 2009a, 2009b), we know little about how entrepreneurs continue to achieve work-life balance when the work aspect of this relationship has ended in failure. For instance, is an entrepreneur able to compartmentalize 
a failure into his or her work micro-identity, thus making the failure have minimal effect on other micro-identities (e.g., the "spouse" microidentity), or does the failure lead to spillover effects? If some are able to compartmentalize the identity experiencing the failure, then it is important to gain an understanding of how the micro-identity experiencing failure is "insulated" from the individual's other micro-identities - that is, how is the "contagion" stopped from affecting other micro-identities and important others (e.g., family members). Although insulation may reduce the extent of failure's harm, perhaps engaging other micro-identities to confront the failure experience (rather than hide from it or insulate it) can provide better outcomes for the entrepreneur (or for some entrepreneurs some of the time). This line of research can be pursued, for example, by finding out whether divorce rates rise after major business or project failures and whether differences in this social cost can be explained by the ways entrepreneurs manage their micro-identities after experiencing failure. Future research addressing these topics will provide deeper insights into failure's social costs and will hopefully enable entrepreneurs to reduce such costs while maximizing the social benefits possible after failure.

\section{The Emotional Implications of Entrepreneurial FAILURE}

When individuals experience the failure of a business or project that was important to them, they can have a negative emotional reaction-namely, grief (Shepherd, 2003; Shepherd \& Cardon, 2009; Shepherd, Covin, et al., 2009; Shepherd et al., 2011). While grief can motivate individuals to seek information about a failure, which is required for learning (Cyert \& March, 1963; Kiesler \& Sproull, 1982), it often disrupts the attention allocation and information processing entrepreneurs need to learn from their failure experiences (consistent with Bower, 1992; Fredrickson, 2001). Based on previous research, we know that negative emotions can have adverse effects on cognitions. First, negative emotions "narrow individuals' momentary thought-action repertoire by calling forth specific action tendencies (e.g., attack, flee) ... [whereas] many positive emotions broaden individuals' momentary thought-action repertoires, prompting them to pursue a wider range of thoughts and actions than is typical" (Fredrickson \& Branigan, 2005, p. 314). Thus, individuals who want to generate original innovations that result in future products should avoid negative emotions (Fredrickson, 1998). Second, research has shown that 
negative emotions have a harmful effect on individuals' commitment, including on entrepreneurs' motivation to start another venture after previous business failure (Shepherd, 2003) or on team members' desire to put forth personal resources to meet organizational objectives after project failure (Allen \& Meyer, 1990; O'Reilly \& Chatman, 1986; Shepherd et al., 2011). While being committed to an action can improve performance, this commitment needs to be balanced with learning from failure because learning from failure can also improve performance (McGrath, 1999). Finally, research has found that negative emotions "narrow people's attention, making them miss the forest for the trees" (Fredrickson, 2001 , p. 222); disrupt creative and integrative thinking (Estrada, Isen, \& Young, 1997; Fredrickson \& Branigan, 2005; Isen, Daubman, \& Nowicki, 1987); and, ultimately, inhibit learning (Fredrickson \& Branigan, 2005; Masters, Barden, \& Ford, 1979). As time passes (i.e., after the failure), these negative emotions tend to dissipate (Shepherd et al., 2011), thereby eliminating barriers to learning from failure.

However, it appears that these emotional obstacles to learning from failure can be reduced more quickly for some individuals (e.g., those with learned optimism [Cardon \& McGrath, 1999] and self-compassion [Shepherd \& Cardon, 2009]) and for those embedded within certain groups (e.g., the family [Shepherd, 2009]) and/or embedded in certain organizations (Shepherd, Covin, \& Kuratko, 2009; Shepherd et al., 2011). Previous studies provide a solid foundation for understanding how and why negative emotional reactions are triggered after failure upon which we can build to explore a number of important research topics.

The emotions that make up grief from entrepreneurial failure. Previous studies have used the term grief when referring to any of the negative emotions caused by the loss of a business (Byrne \& Shepherd, 2015; Shepherd, 2003, 2009) or project (Shepherd \& Cardon, 2009; Shepherd, Covin et al., 2009, 2011), and current research has investigated how grief (used as an umbrella term) affects cognitive processes related to learning. However, research on emotions has shown that different forms of negative emotions have distinct sources as well as varying impacts on cognition (Bodenhausen, Sheppard, \& Kramer, 1994; Keltner, Ellsworth, \& Edwards, 1993). As such, do specific failures result in different psychological outcomes because they cause different forms of negative emotions that in turn affect cognitive processes in distinct ways? Some failures for some people are likely to generate feelings of shame, while other failures may cause feelings of guilt in other individuals. These 
are related but distinct negative emotions, both of which can contribute to the feeling of grief but can have different effects on cognition. Shame over a failure involves an evaluation of the self such that one feels that he or she is a "bad person," whereas guilt over a failure involves an evaluation of the behavior such that one feels that he or she has done a "bad thing" (Lewis, 1971; Niedenthal, Tangney, \& Gavanski, 1994; Tangney, 1989, 1991, 1993). How do these differences between shame and guilt (as contributors to grief over the loss generated by failure) influence the cognitive process of learning from failure and the motivational process of trying again? Additionally, it is important to understand the processes for dealing with shame and distinguish them from the processes of dealing with guilt. Such an understanding of the distinct antecedents, roles, and effects of the different negative emotions that make up grief over failure will not only help explain the psychological implications of failure but will also have some normative implications-namely, we will learn how to facilitate the grief-recovery process to maximize and accelerate learning from the experience and to regain motivation and positive functioning.

Moreover, could a combination of particular negative emotions comprising the entrepreneur's grief (contingent and/or configuration) better explain the psychological costs stemming from failure compared to the impact of each of these emotions separately (main effects)? There is an opportunity to explore the different configurations of negative emotions that make up grief across individuals, failures, and/or situations. What is perhaps even more interesting is to investigate these configurations over time. For example, it could be that for a group of entrepreneurs, a particular negative emotion dominates immediately after the failure (e.g., anger) but then declines shortly after, whereas another negative emotion may have low salience early but comes to dominate later (e.g., guilt). It will be interesting to determine whether entrepreneurs feel a "sequence" of negative emotions; whether different individuals, failures, and/or situations have different sequences; and what psychological implications these different sequences have for the entrepreneurs whose projects or businesses failed.

Building resources from entrepreneurial failure experiences. Exploring the psychological costs of the negative emotions associated with business failure is a worthwhile and interesting endeavor, and there is still a great deal of work to be done in this area (see previous point). However, future research should also explore the positive psychological effects of grief after business failure. Research on grief has shown that for some 
individuals who experience grief after a loved one dies, going through the grieving process leads to personal growth (Hogan, Greenfield, \& Schmidt, 2001). Researchers have the opportunity to gain a deeper understanding of this notion of personal growth over and above merely recovering from the experience (Cope, 2011; Shepherd, 2003; Shepherd et al., 2011), which in turn leads to several interesting questions. After business failure, do entrepreneurs realize they have emotional and cognitive resources they did not notice before, and/or does experiencing failure help them build such resources? For instance, handling failure may help entrepreneurs develop coping self-efficacy, emotional intelligence, and other sources of resilience. These resilience resources (and self-knowledge of them) are likely to impact subsequent entrepreneurial thinking in terms of, for example, the willingness to bear uncertainty, which in turn influences the formation of opportunity beliefs. That is, resilience resources can lead to a greater emotional investment in an entrepreneurial course of action given the belief in one's ability to effectively deal with negative emotional reactions if it were to fail. These resources can also result in less reliance on sunk costs and a decreased need to appear consistent, which will help reduce persistence with a poorly performing project or business given the individual's confidence in being able to deal with the consequence of failure.

Positive emotions in the aftermath of entrepreneurial failure. Exploring the role of positive emotions and self-regulation is also likely to lead to a deeper understanding of personal growth from business failure. Fredrickson $(1998,2003)$, for example, showed that positive emotions can counter the influence negative emotions have in limiting attention and information processing and can help develop resources that aid in coping with difficulty. Thus, do entrepreneurs with more dispositional optimism (e.g., see Hmieleski \& Baron, 2009) and positive affect (e.g., see Baron, Tang, \& Hmieleski, 2011) realize greater advantages from failure experiences (e.g., recover more rapidly, learn more successfully and experience more personal growth)? As opposed to depending on trait affect, maybe entrepreneurs proactively utilize positive emotions to cope with grief resulting from business failure. If they do, however, how are they able to generate such positive emotions after such a significant loss? Perhaps this is where emotional intelligence plays a particularly important role. That is, emotionally intelligent entrepreneurs are likely to be aware of their highly negative emotions from project or business failure, realize that the generation of positive emotions both "undoes" negative emotions and helps build resources (Fredrickson, 1998), and know how to trigger these 
positive emotions. It is the last of these actions that might be easier said than done-namely, generating positive emotions when one is "feeling blue" from a major failure can be a difficult task. How are some people able to trigger positive emotions after a failure or other form of major loss?

Therefore, understanding the techniques for stimulating positive emotions may be particularly helpful for entrepreneurs who frequently face failures and other major setbacks. Such techniques could include watching a comedy or telling oneself a joke. Alternatively, it may be less about the entrepreneur's possession of emotional intelligence him- or herself but more about having emotionally intelligent individuals in his or her network. For example, individuals who are able to generate positive emotions to remove the obstacles to learning from failure and moving on from the event might be those with friends who (1) recognize that their entrepreneur friend is experiencing negative emotions and has a need for positive emotions and (2) know how to generate those positive emotions in him or her. Again, gaining a deeper understanding of the "who" and the "how" of generating positive emotions in a loss situation is likely to be highly important in advancing our understanding of both the emotional costs and benefits of project and business failure. This stream of research may have an interesting implication for entrepreneurship education-teaching our students how to stimulate positive emotions even in the most adverse of situations.

Multiple entrepreneurial failures. While research has begun exploring the "hot cognitions" related to failure for entrepreneurs, there has been limited research exploring the implications of multiple failures (for exceptions, see Shepherd, Haynie, \& Patzelt, 2012; Ucbasaran, Westhead, \& Wright, 2009; Ucbasaran et al., 2010). For instance, are the psychological costs of a second failure different than those of a first failure, and if so, how? The entrepreneur could be more psychologically equipped to cope with a second failure due to his or her previous failure experience. Alternatively, the entrepreneur could still be dealing with unresolved issues from the first failure that make issues associated with the subsequent failure even worse- a form of accumulated grief (Shepherd et al., 2012). The trial-by-fire model (Swaminathan, 1996) may explain differences between those experiencing their first failure and those experiencing subsequent failure-at least in part. More specifically, among those who experience failure, only those who are "psychologically" strong (through self-selection or learning) will try again and thus suffer fewer psychological consequences from a second failure than those experiencing their first failure. 
Also, consistent with the trial-by-fire model, individuals learn from their failures about how best to deal with failure (i.e., build resources and capabilities that promote resilience) and are thus able to more quickly recover, learn, and try again. However, we also know that continual exposure to difficult events can lead to a form of desensitization such that adverse stimuli no longer generate negative emotional reactions (Ashforth \& Kreiner, 2002). Do entrepreneurs who have suffered many failures become desensitized to failure such that a failure no longer generates a negative emotional reaction? As authors, we have certainly had so many papers rejected that the "sting" of a rejection is no longer as painful as it once was. If we consider no emotional reaction to be cold cognition, how are the decision-making process and reactions as part of the entrepreneurial process different from a hotter form of cognition? It seems that too much "hot" is detrimental to cognitive performance (e.g., in terms of obstructing learning), but are there negative consequences from the cognition being too cold? May be there is an optimal amount of heat and/or maybe more heat is necessary for some cognitive tasks but less for other cognitive tasks. We believe there is ample opportunity to contribute further insights into the inter-relationship between multiple failure experiences and hot cognition in understanding the costs and benefits for entrepreneurs after failure.

\section{Multiple and Inter-Related Implications of Entrepreneurial Failure}

The inter-relationship between the financial and social implications of failure. The more we study the social implications of entrepreneurial failure, the more insights we will gain into its financial implications. For instance, are there financial implications for entrepreneurs after business failure as a result of damage to their ventures or informal networks? The direct financial costs resulting from failure, such as the loss of wealth or remaining debt, may result in less hardship than the indirect financial costs stemming from a damaged reputation and loss of status, which may have a longer-lasting negative impact. If this is the case, initial attempts at recovery are likely to be more successful if they are aimed at maintaining one's network (or rapidly repairing it or developing a new one) as opposed to overcoming direct financial costs. By taking a closer look at the connection between the social and financial costs of business failure for entrepreneurs, we will begin to gain a deeper understanding of why some recovery strat- 
egies are more useful than others and perhaps how we can teach entrepreneurs (and budding entrepreneurs) how to "manage" failure to more quickly recover from its negative consequences. Alternatively, it could be the opposite sequence that facilitates recovery-that by recovering financially, the individual then has an easier time regaining and repairing his or her formal business network and creating a new network. We suspect that the process is more iterative and reciprocal-namely, as the entrepreneur starts to financially recover from the failure, his or her network relationships start to be repaired, which helps the entrepreneur recover financially, which helps with social recovery, and so on in the form of a virtuous spiral. The important research questions then become what factors start, perpetuate, and stop these virtual spirals, and are they the same factors that stop or slow a vicious spiral.

The inter-relationship between the social and emotional/psychological implications of entrepreneurial failure. Losing a business is often a very personal experience; however, some failures are more public. For instance, in project failure, employees are told the project is terminated, the team is disbanded, and people are redeployed to others projects. When it comes to business failure, the physical business is closed, employees vacate the factory or office, and customers and suppliers eventually find out about the business failure. The extent of the public nature of the failure (and its associated social costs) is likely to impact the entrepreneur's emotional reaction to the failure and its psychological costs. For example, when it comes to project failure, organizational culture can have an important influence on the "social evaluation" of those who fail (Cannon \& Edmondson, 2001) and, in doing so, likely has a psychological impact on those who act entrepreneurially, particularly those who experience failure.

Although we expect that the public nature of a failure will increase its social costs, which will in turn exacerbate the psychological costs, perhaps a public failure leads to different social costs such that the psychological costs of a highly public failure are less than the psychological costs of hiding the failure from others (in an attempt to reduce the social costs). It could be that public failures generate unexpected social and psychological benefits, such as support groups being formed to help the entrepreneur deal with the failure that might have otherwise not been available if these others were not aware of the failure. Like for other hidden stigmas (Pachankis, 2007), anxiety and stress about keeping the failure hidden from the public is likely to generate negative psychological and perhaps physical consequences for the entrepreneur. In this way, in terms of failure 
and its public nature, maybe the entrepreneur is better off disclosing than hiding. Indeed, by disclosing the failure rather than having others find out about it on their own, the entrepreneur can use impression-management strategies to minimize the social (and perhaps also the financial) implications of the failure event (Sutton \& Callahan, 1987).

The inter-relationship between the emotional and cognitive implications of entrepreneurial failure. Research on bereavement has shown that some losses are more likely than others to result in complicated griefnamely, elevated grief and grief over an extended period of time (Neimeyer, 2006). For instance, parents whose children commit suicide often have complicated grief, and their feelings of grief are frequently made worse by additional feelings of shame and embarrassment, thereby making it more challenging to "talk through their grief" with others (Mitchell, Mitchell, \& Smith, 2004). As a result, others may find it more difficult to start discussions as they worry about saying the "wrong thing" (Nolen-Hoeksema \& Davis, 1999). Shame and embarrassment are psychological costs caused by the expectation of others' judgments and lead those experiencing such feelings to avoid others and, as a consequence, to incur social costs, such as loneliness. Under what circumstances (i.e., characteristics of the entrepreneur and/or of the social context) can feelings of embarrassment and shame over failure be lessened or even eliminated? We know that grief is lower in environments where failure is normalized (Ashforth \& Kreiner, 2002; Shepherd et al., 2011), but perhaps attempts to take emotion out of the entrepreneurial process undermine the emotional commitment necessary to form a strong team, persist through challenges, and make an entrepreneurial endeavor a success. Ironically, by avoiding the negative emotions of failure (by taking emotions out of the process), the entrepreneur may be making failure a more likely outcome for the focal project or business.

The inter-relationship between the financial and psychological implications of entrepreneurial failure. There is also an opportunity for future research to further investigate the relationship between the financial costs and the psychological costs of entrepreneurial failure. Do the psychological costs stemming from business failure have financial implications? The psychological costs of business failure may not only be a barrier to learning from failure but could also obstruct the entrepreneur of a failed business from moving on to generate a new income source (the delay of which makes the financial costs of business failure even worse). For example, if the entrepreneur ruminates over his or her business failure, it may 
inhibit him or her from interviewing for a new job or seeking out new venture opportunities. On the other hand, the psychological costs of the failure could be obvious to potential employers during the interview process (e.g., the person does not demonstrate adequate enthusiasm or self-belief to assure the prospective employer that he or she can successfully take on the new role), ultimately leading to the individual's failure in securing the position. Similarly, the psychological costs of failure may represent an obstacle to the team member of a failed project that prevents him or her from recommitting to the organization and enjoying the financial rewards of those efforts (e.g., promotion and bonus). That is, the psychological costs of project failure mean that the employee is less enthusiastic about subsequent roles and projects, is less committed to the organization, and has less positive interactions with management, all of which can have negative implications for his or her career within the organization.

In terms of individuals' recovery from the financial and psychological costs of entrepreneurial failure, does sequence matter? Perhaps an entrepreneur has to lessen the psychological costs of business failure before trying to recover from the financial costs (i.e., acquiring employment and pursuing his or her next entrepreneurial endeavor), or perhaps he or she needs to reduce the financial costs first, which will diminish one of the major stressors of business failure and thereby help reduce the psychological costs. Likewise, perhaps an employee needs to focus on overcoming the psychological costs of failure before focusing on the financial implications in terms of career progression. By extension, the organization may need to focus on the psychological costs of project failure for its employees first and then the sequence of roles that advance those employees' careers. Alternatively, by fully focusing on the next project as a way to advance one's career, the employee can reduce the financial implications of the loss and thus reduce the failure's psychological costs (there is some evidence of this approach by engineers [Shepherd, Patzelt, Williams, \& Warnecke, 2014]). Because there are still so many unknowns regarding this topic, future research on the inter-relationship between the financial and psychological costs (perhaps even the spiral involving a reciprocal relationship between the two) of business failure can make important contributions to our understanding of the consequences of such failure.

A multi-disciplinary and multi-level approach to understanding the implications of entrepreneurial failure. Research investigating the inter-connections of the different types of business failure costs has substantial promise, and we believe that such research will likely necessitate 
multi-disciplinary and/or multi-level theorization and empirical testing. Exploring the inter-relationship between financial and social costs, for instance, may require researchers to build on (and ultimately contribute to) theories of both stigmatization and venture capital markets to provide deeper insights into why some entrepreneurs who have experienced business failure in certain regions are able to obtain the funds required to start a new entrepreneurial venture, whereas other entrepreneurs who have experienced business failure in other regions are unable to obtain such funds. Similarly, investigating the inter-relationship between financial and social costs may require building on (and ultimately making contributions to) theories of both management decision making and organizational culture to gain a deeper understanding of why employees who have experienced project failure in some organizations are celebrated and promoted, whereas employees who have experienced project failure in other organizations are ostracized and demoted. Due to the drastic change in the entrepreneur's social context (for a public failure) and the often extreme feelings accompanying loss after failure, research exploring both the social and psychological costs of failure is likely to make important extensions to current theories of social cognition.

\section{Sensemaking of Entrepreneurial Failure}

Making sense of loss has been found to be critical to recovery efforts (Davis, Nolen-Hoeksema, \& Larson, 1998; Park, 2010). A sensemaking perspective argues that learning from failure requires one to continuously develop plausible retrospective accounts that in turn shape current behavior (Weick, Sutcliffe, \& Obstfeld, 2005). The changed beliefs that result then alter the actions the individual takes, thereby improving the likelihood of future project/business success. If the individual fails to develop and use increasingly more plausible accounts for the failure, anxiety may paralyze decision making and action (Lüscher \& Lewis, 2008; Smircich \& Morgan, 1982). The resulting lack of action will decrease the experimentation and social interactions required for successful learning (Balogun \& Johnson, 2004; Maitlis, 2005). A few underlying assumptions of the sensemaking perspective are that constraints (e.g., those causing failure) are self-imposed and that the environment is not pre-decided nor is it beyond one's control, both of which are notions in line with the idea of an enacted environment (Daft \& Weick, 1984; Gioia \& Chittipeddi, 1991; Weick et al., 2005). Future research can add to this body of knowledge by exploring entrepreneurial failure using a sensemaking perspective. 
Sensemaking of entrepreneurial failure involves action. Because plausibility plays an important role in explaining subsequent action (Weick et al., 2005), we need to better understand the way entrepreneurs create and/or generate plausible accounts of failure. These accounts-namely, the stories we tell ourselves and others-are plausible when the individual thinks they can be true (Epley \& Gilovich, 2006), and they become increasingly more plausible as the individual's thoughts and actions to substantiate the proposed story provide satisfactory proof to alter beliefs about why the event at hand (e.g., failure) happened. It could be that entrepreneurs who take more actions are able to create/generate more plausible stories. Indeed, action is an important mechanism of sensemaking as the individual uses the feedback of his or her actions to enhance the plausibility of the enacted and emerging story. What are the initial actions that entrepreneurs take after failure that reflect the initial story of failure and also provide the greatest feedback to enhance the plausibility of that story (without necessarily exacerbating the problems and issues generated by the failure in the first place)? By studying the reciprocal relationship between activities and the development of a plausible story, we can begin to develop a behavioral micro-foundation of learning from failure.

Individual differences in the sensemaking of entrepreneurial failure. There are likely to be different individual variables that help explain the extent and/or the speed at which a story for failure becomes plausible and are used to initiate entrepreneurial action. Individuals who have the greatest prior knowledge of a particular domain or of the entrepreneurial process are likely to be those who are best able to combine an emerging story of failure with a subsequent opportunity belief to guide the next step in the entrepreneurial process. Does education or specific experience (e.g., industry-specific experience) play a role here? Perhaps those with greater education and/or experience are better able to think in the abstract to connect the dots of the failure to come up with a plausible story and/or are better able to communicate that story and interpret feedback to improve its plausibility. Furthermore, self-compassion (Neff, 2009; Shepherd \& Cardon, 2009) likely helps entrepreneurs disengage ego-protective mechanisms that would otherwise restrict thinking and creativity that could obstruct the construction, revision, and further development of a plausible story. Additionally, analogical thinking facilitates creative thinking and the development of explanations by individuals in novel domains (Dahl \& Moreau, 2002; Gick \& Holyoak, 1983), including entre- 
preneurs thinking about potential opportunities (Grégoire, Barr, \& Shepherd, 2010; Grégoire \& Shepherd, 2012). Perhaps individuals skilled at analogical thinking are better able to connect the dots revealed through entrepreneurial failure to create a plausible story of the past to inform future actions. Similarly, mindfulness relates to a "heightened state of involvement and wakefulness or being in the present" that can be useful in "actively drawing novel distinctions" (Langer \& Moldoveanu, 2000, p. 2; see also Brown \& Ryan, 2003; Langer, 1989). Mindful individuals have an enhanced quality of attention, which is likely to facilitate sensemaking efforts (Weick \& Sutcliffe, 2006). This form of mindfulness may be an important skill that some individuals have (and others can learn) to facilitate the process of failure sensemaking. Finally, it could be that individuals with greater metacognitive awareness - those who think about their thinking (Haynie, Shepherd, Mosakowski, \& Earley, 2010; Haynie, Shepherd, \& Patzelt, 2012) - are most likely to reflect on the current situation in light of their recent failure to develop a plausible story that informs and motivates entrepreneurial action. All of the above variables deserve additional attention, and we believe that taking a sensemaking perspective of failure is likely to push the theoretical boundaries of story construction after a negative event like failure.

Sensemaking of entrepreneurial failure over time. It is important to remember that plausible stories of a failure are temporary outcomes of the sensemaking process. Throughout this process, one plausible story of business failure is exchanged for another "more" plausible story. However, what remains uncertain is how this process unfolds and when it terminates. It could be that immediately after business failure, the entrepreneur creates stories rapidly and then quickly updates those stories as new information provides feedback to improve their plausibility. On the other hand, it could be that the story reaches saturation over time such that additional data provide little useful information. It could also be that sensemaking transforms from making sense of a failure to making sense of one's present situation, which would mean that making sense of the failure becomes less important. Thus, future research is needed to better explain the patterns of plausible stories of failure-specifically, researchers should elucidate the antecedents to and consequences of differences in entrepreneurs' "plausibility updating." That is, why are some quick to update the plausibility of a failure story and others slow to do so, and why do some stop updating when they do? 
Not only is it interesting to think about the possible antecedents to the different patterns of failure sensemaking but also to investigate its outcomes. Obviously, one outcome is plausibility, but are there tradeoffs to achieving this plausibility - are financial, emotional, and social costs exacerbated by efforts to quickly develop plausibility? Similarly, perhaps some failure sensemaking patterns magnify the financial, emotional, and social costs of entrepreneurial failure, while other sensemaking patterns diminish them. Moreover, as we discussed above, what may diminish one cost of failure may work in concert with or against other costs of failure. For example, some efforts to enhance the plausibility of the entrepreneurial failure story may help reduce the mental anguish the entrepreneur has over the failure experience but at the same time increase the financial costs of the failure (e.g., because the reflection necessary for enhancing plausibility may take time away from new income-generating actions). There are many opportunities to explore the different patterns, contingencies, and other configurations that involve sensemaking and the implications of failure over time.

The role of others in the sensemaking of entrepreneurial failure. After crises, collective sensemaking can enable the development and redevelopment social structure-namely, the social roles and relationships in certain groups of actors (e.g., Weick, 1995). However, what happens when the organization (i.e., in the case of business failure) or the team (i.e., in the case of project failure) around which that social structure was built no longer exists? Do individuals (e.g., entrepreneurs and investors) merely undertake their own sensemaking and carry on, or is there another basis or forum for the collective sensemaking process? When entrepreneurial team members and/or employees take part in collective sensemaking, which aids in learning and recovery, is the likelihood of attribution bias (i.e., developing more plausible stories) reduced, or do these kinds of biases extend to the team? The answers to these questions likely reflect attributes of the team, such as team members' emotional capabilities (see Shepherd, 2009) and/or the cognitive diversity within the group (Kilduff, Angelmar, \& Mehra, 2000).

Although team members of a project may feel isolated from others after project failure, which inhibits the opportunity for collective sensemaking, these feelings of isolation and lack of opportunities for collective sensemaking may be particularly pronounced for entrepreneurs of failed businesses. To what extent do members of the founding team come together after a business has failed to engage in collective 
sensemaking? What about solo entrepreneurs - with whom do they try to engage for the purpose of collective sensemaking? Perhaps these entrepreneurs can try to engage with former stakeholders of the failed business to facilitate failure sensemaking, but it may be a difficult task to engage with previous stakeholders (they have to be found, and the entrepreneur may feel guilty that he or she let them down). On the one hand, it could be that approaching these former stakeholders, despite facilitating sensemaking, may exacerbate the emotional costs of failure-namely, generate additional negative emotions by making others' painful experiences resulting from the business failure more salient. On the other hand, overcoming the anticipation of a negative stakeholder response, the entrepreneur might find it therapeutic to talk with the stakeholders and perhaps find that their response is not as negative as anticipated. Such engagement may also help the stakeholders deal with their negative emotional reaction to the failure. Indeed, helping stakeholders deal with the failure may improve the entrepreneur's own emotional state, and the enhanced sensemaking from engaging these knowledgeable individuals may enhance the plausibility of the failure story, thus helping to break emotional bonds to the lost object (Stroebe \& Schut, 2001).

In Fig. 3.1, we offer a sketch of a model of the implications of failure as part of the entrepreneurial process. Entrepreneurial failure (i.e., failure of a project or business) has implications financially (personal and business), socially (e.g., stigma and relationship ties), emotionally (e.g., grief and positive emotions), and psychologically (in terms of the needs for competence, relatedness, and autonomy). The impact of entrepreneurial failure on these implications can be magnified or dampened depending on the culture in which the individual is embedded as well as the attributes of the individual (e.g., social skills, positive emotions, supportive others, and failure role models). The attributes of the individual are inter-related, and some are influenced by culture (and vice versa). The financial, social, emotional, and psychological implications independently and inter-dependently influence entrepreneurs' learning from failure, motivation to try again, and level of resilience resources and capabilities, which in turn influence subsequent entrepreneurial action. Learning, motivation, and resilience influence the culture and the attributes of the individual, and entrepreneurial action can influence individuals' positive emotions. 


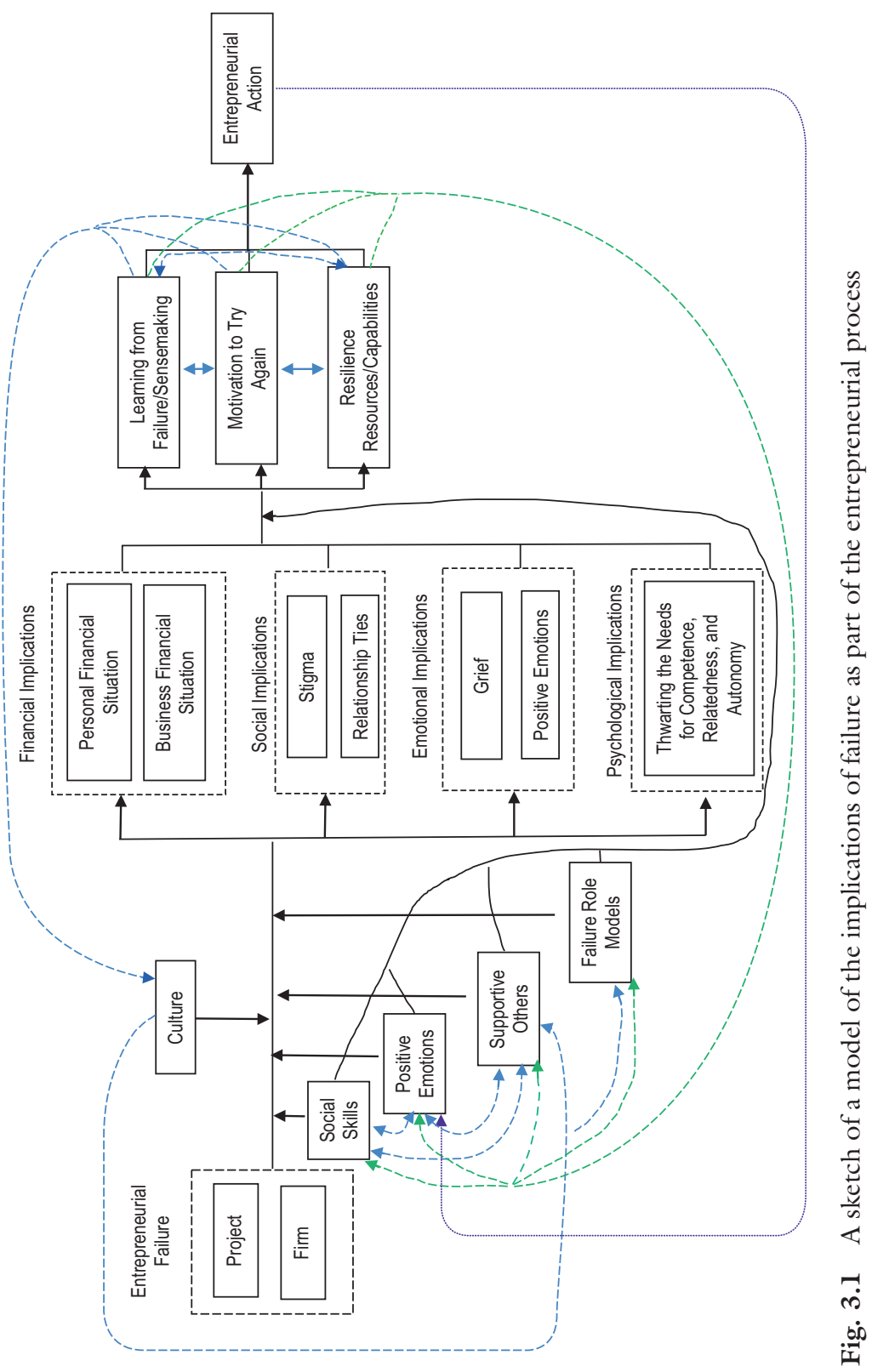




\section{Discussion And Conclusion}

With the recognition that "opportunity" is central to entrepreneurship and that opportunities are shrouded in uncertainty, a logical next step is to embrace the importance of understanding the implications of entrepreneurial failure. Entrepreneurial action and failure go hand in hand (given the high uncertainty), and we have only scratched the surface of this relationship. Whether exploring the actions of independent entrepreneurs in their newly founded (or emerging) organizations or those of corporate entrepreneurs in their innovative projects within established organizations, the nature of failure and its financial, social, emotional, and psychological implications likely have a critical impact on subsequent entrepreneurial action. However, despite its "criticality," we are just starting to gain an understanding of the complexity of the many interwoven relationships at play for these failure events.

Although it is important to continue to explore main-effect unidirectional causal relationships, it will also be important to progress to multiple contingent/configurational mutually causal relationships of the antecedents and consequences of failure as the basis for a more dynamic micro-foundation theory of entrepreneurial action. That is, scholars need to overcome their anti-failure bias (McGrath, 1999) to better understand the decision making, cognitions, emotions, relationships, and behaviors of those involved in the entrepreneurial process. We believe that such research will help reconcile a number of paradoxes. A paradox involves "contradictory yet inter-related elements that exist simultaneously and persist over time" (Smith \& Lewis, 2011, p. 382). Being able to identify the underlying tension between two sets of relationships that seem to make sense when they are viewed individually but appear to be contradictory when viewed at the same time can lead to theorizing as an approach to resolving the paradox (Shepherd \& Suddaby, 2017).

Specifically, we can work toward the following:

1. Reconciling the perspective of "fail often and quickly" (e.g., real options reasoning [McGrath, 1999; McGrath \& Nerkar, 2004] and design thinking [Brown, 2008; Brown \& Wyatt, 2015]) with the perspective that failure "hurts" for those who directly experience it (Byrne \& Shepherd, 2015; Shepherd, 2003; Shepherd et al., 2011).

2. Reconciling the perspective that failure is a badge of honor (e.g., Landier, 2004) with the perspective that failure can stigmatize-put a denigrating stain or mark on-those involved with the failure 
(Semadeni et al., 2008; Shepherd \& Patzelt, 2015; Sutton \& Callahan, 1987).

3. Reconciling strategies that try to avoid failure (e.g., risk-reduction strategies [Azadegan, Patel, \& Parida, 2013; Shepherd, Douglas, \& Shanley, 2000]) with strategies that make failure more likely and frequent (Brown, 2008; Brown \& Wyatt, 2015; McGrath, 1999; McGrath \& Nerkar, 2004).

4. Reconciling the financial benefits of terminating a poorly performing project (Bakker \& Shepherd, 2017; McGrath \& Keil, 2007) or firm (Ansic \& Pugh, 1999) early with the prevalence of permanently failing projects (Hisrich \& Cahill, 1995) and firms (Meyer \& Zucker, 1989; van Witteloostuijn, 1998).

5. Reconciling the benefits of a strategy based on a big bet for a big win (Courtney, Kirkland, \& Viguerie, 1997; Ireland \& Miller, 2004) with the benefits of making numerous small probes and sequential investments with many small failures (Adner \& Levinthal, 2004; Brown \& Eisenhardt, 1997).

6. Reconciling taking emotions out of project and business failures (e.g., desensitization and normalization of failure [Ashforth \& Kreiner, 2002]) with emotional investments that enhance project (Akgün, Keskin, Byrne, \& Gunsel, 2011; Rank \& Frese, 2008) and business performance (for a meta-analysis, see Meyer, Stanley, Herscovitch, \& Topolnytsky, 2002).

7. Reconciling the negative emotions of failure that obstruct learning (Shepherd, 2003; Shepherd et al., 2011) with the negative emotions that capture attention and stimulate sensemaking (Nolen-Hoeksema, 1998; Schwarz, Bless, \& Bohner, 1991).

8. Reconciling the opportunity lost as a result of the decision to terminate (Drummond, 2005; Roberts \& Weitzman, 1981) with the opportunity cost of missed opportunities caused by delaying termination (Gimeno et al., 1997; Shepherd et al., 2014).

9. Reconciling the use of predetermined stage gates to rapidly terminate a potential opportunity that does not show promise (Cooper, 2008; Cooper \& Kleinschmidt, 1993) with the premature termination of a potential opportunity that could otherwise have been changed and refined through learning and adapting the stage-gate criteria (McGrath \& Keil, 2007; see also Chap. 4).

So many paradoxes, so many research opportunities, so exciting! 


\section{REFERENCES}

Adner, R., \& Levinthal, D. A. (2004). What is not a real option: Considering boundaries for the application of real options to business strategy. Academy of Management Review, 29(1), 74-85.

Akgün, A. E., Keskin, H., Byrne, J. C., \& Gunsel, A. (2011). Antecedents and results of emotional capability in software development project teams. Journal of Product Innovation Management, 28(6), 957-973.

Allen, N. J., \& Meyer, J. P. (1990). The measurement and antecedents of affective, continuance and normative commitment to the organization. Journal of Occupational Psychology, 63(1), 1-18.

Ansic, D., \& Pugh, G. (1999). An experimental test of trade hysteresis: Market exit and entry decisions in the presence of sunk costs and exchange rate uncertainty. Applied Economics, 31(4), 427-436.

Ardichvili, A., Cardozo, R., \& Ray, S. (2003). A theory of entrepreneurial opportunity identification and development. Journal of Business Venturing, 18(1), $105-123$.

Arnold, J., \& Cohen, L. (2008). The psychology of careers in industrial and organizational settings: A critical but appreciative analysis. In G. Hodgkinson \& J. K. Ford (Eds.), International review of industrial and organizational psychology (Vol. 23, pp. 1-44). London: John Wiley \& Sons Ltd.

Ashforth, B. E., \& Kreiner, G. E. (2002). Normalizing emotion in organizations: Making the extraordinary seem ordinary. Human Resource Management Review, 12(2), 215-235.

Azadegan, A., Patel, P. C., \& Parida, V. (2013). Operational slack and venture survival. Production and Operations Management, 22(1), 1-18.

Baker, T., \& Nelson, R. E. (2005). Creating something from nothing: Resource construction through entrepreneurial bricolage. Administrative Science Quarterly, 50(3), 329-366.

Bakker, R. M., \& Shepherd, D. A. (2017). Pull the plug or take the plunge: Multiple opportunities and the speed of venturing decisions in the Australian mining industry. Academy of Management Journal, amj-2013.

Balogun, J., \& Johnson, G. (2004). Organizational restructuring and middle manager sensemaking. Academy of Management Journal, 47(4), 523-549.

Baron, R. A., \& Tang, J. (2009). Entrepreneurs' social skills and new venture performance: Mediating mechanisms and cultural generality. Journal of Management, 35(2), 282-306.

Baron, R. A., Tang, J., \& Hmieleski, K. M. (2011). The downside of being 'up': Entrepreneurs' dispositional affect and firm performance. Strategic Entrepreneurship Journal, 5(2), 101-119.

Bodenhausen, G. V., Sheppard, L. A., \& Kramer, G. P. (1994). Negative affect and social judgment: The differential impact of anger and sadness. European Journal of Social Psychology, 24(1), 45-62. 
Bosma, N., Hessels, J., Schutjens, V., Van Praag, M., \& Verheul, I. (2012). Entrepreneurship and role models. Journal of Economic Psychology, 33(2), 410-424.

Boulding, W., Morgan, R., \& Staelin, R. (1997). Pulling the plug to stop the new product drain. Journal of Marketing Research, 34(1), 164-176.

Bower, G. H. (1992). How might emotions affect learning. In S. Christianson (Ed.), The handbook of emotion and memory: Research and theory (pp. 3-31). New York: Psychology Press.

Bradley, S. W., Wiklund, J., \& Shepherd, D. A. (2011). Swinging a double-edged sword: The effect of slack on entrepreneurial management and growth. Journal of Business Venturing, 26(5), 537-554.

Brown, T. (2008). Design thinking. Harvard Business Review, 86(6), 84-92.

Brown, S. L., \& Eisenhardt, K. M. (1997). The art of continuous change: Linking complexity theory and time-paced evolution in relentlessly shifting organizations. Administrative Science Quarterly, 42, 1-34.

Brown, K. W., \& Ryan, R. M. (2003). The benefits of being present: Mindfulness and its role in psychological well-being. Journal of Personality and Social Psychology, 84(4), 822-848.

Brown, T., \& Wyatt, J. (2015). Design thinking for social innovation. Annual Review of Policy Design, 3(1), 1-10.

Brüderl, J., Preisendörfer, P., \& Ziegler, R. (1992). Survival chances of newly founded business organizations. American Sociological Review, 57(2), 227-242.

Burgelman, R. A., \& Välikangas, L. (2005). Managing internal corporate venturing cycles. MIT Sloan Management Review, 46(4), 26-34.

Byrne, O., \& Shepherd, D. A. (2015). Different strokes for different folks: Entrepreneurial narratives of emotion, cognition, and making sense of business failure. Entrepreneurship Theory and Practice, 39(2), 375-405.

Campbell, A., Birkinshaw, J., Morrison, A., \& van Basten Batenburg, R. (2003). The future of corporate venturing. MIT Sloan Management Review, 45(1), 30-38.

Cannon, M. D., \& Edmondson, A. C. (2001). Confronting failure: Antecedents and consequences of shared beliefs about failure in organizational work groups. Journal of Organizational Behavior, 22(2), 161-177.

Cannon, M. D., \& Edmondson, A. C. (2005). Failing to learn and learning to fail (intelligently): How great organizations put failure to work to innovate and improve. Long Range Planning, 38(3), 299-319.

Cardon, M., \& McGrath, R. G. (1999). When the going gets tough ... Toward a psychology of entrepreneurial failure and re-motivation. Paper presented the Frontiers of Entrepreneurship Research Conference. Babson College.

Chuang, Y. T., \& Baum, J. A. (2003). It's all in the name: Failure-induced learning by multiunit chains. Administrative Science Quarterly, 48(1), 33-59.

Coelho, P. R. P., \& McClure, J. E. (2005). Learning from failure. Mid-American Journal of Business, 20(1), 13-20. 
Cooper, R. G. (2008). Perspective: The stage-gate ${ }^{\circledR}$ idea-to-launch processUpdate, what's new, and nexgen systems. Journal of Product Innovation Management, 25(3), 213-232.

Cooper, R. G., \& Kleinschmidt, E. J. (1993). Major new products: What distinguishes the winners in the chemical industry? Journal of Product Innovation Management, 10(2), 90-111.

Cope, J. (2011). Entrepreneurial learning from failure: An interpretative phenomenological analysis. Journal of Business Venturing, 26(6), 604-623.

Courtney, H., Kirkland, J., \& Viguerie, P. (1997). Strategy under uncertainty. Harvard Business Review, 75(6), 67-79.

Cyert, R. M., \& March, J. G. (1963). A behavioral theory of the firm. Englewood Cliffs, NJ: Prentice-Hall.

Daft, R. L., \& Weick, K. E. (1984). Toward a model of organizations as interpretation systems. Academy of Management Review, 9(2), 284-295.

Dahl, D. W., \& Moreau, P. (2002). The influence and value of analogical thinking during new product ideation. Journal of Marketing Research, 39(1), 47-60.

D'Aveni, R. A. (1990). Top managerial prestige and organizational bankruptcy. Organization Science, 1(2), 121-142.

Davidsson, P., \& Honig, B. (2003). The role of social and human capital among nascent entrepreneurs. Journal of Business Venturing, 18(3), 301-331.

Davis, C. G., Nolen-Hoeksema, S., \& Larson, J. (1998). Making sense of loss and benefiting from the experience: Two construals of meaning. Journal of Personality and Social Psychology, 75(2), 561-574.

Diener, E., \& Seligman, M. E. P. (2002). Very happy people. Psychological Science, $13(1), 81-84$.

Drummond, H. (2005). What we never have, we never miss? Decision error and the risks of premature termination. Journal of Information Technology, 20(3), $170-176$.

Dumas, B. (1992). Dynamic equilibrium and the real exchange rate in a spatially separated world. Review of Financial Studies, 5(2), 153-180.

Efrat, R. (2005). Bankruptcy stigma: Plausible causes for shifting norms. Emory Bankruptcy Development Journal, 22, 481-520.

Efrat, R. (2006). The evolution of bankruptcy stigma. Theoretical Inquiries in Law, 7(2), 365-393.

Epley, N., \& Gilovich, T. (2006). The anchoring-and-adjustment heuristic: Why the adjustments are insufficient. Psychological Science, 17(4), 311-318.

Estrada, C. A., Isen, A. M., \& Young, M. J. (1997). Positive affect facilitates integration of information and decreases anchoring in reasoning among physicians. Organizational Behavior and Human Decision Processes, 72(1), 117-135.

Farson, R., \& Keyes, R. (2006). The failure-tolerant leader. In D. Mayle (Ed.), Managing innovation and change (pp. 249-257). Thousand Oaks, CA: Sage.

Fredrickson, B. L. (1998). What good are positive emotions? Review of General Psychology, 2(3), 300-319. 
Fredrickson, B. L. (2001). The role of positive emotions in positive psychology: The broaden-and-build theory of positive emotions. American Psychologist, $56(3), 218-226$.

Fredrickson, B. L. (2003). Positive emotions and upward spirals in organizations. In K. S. Cameron, J. E. Dutton, \& R. E. Quinn (Eds.), Positive organizational scholarship: Foundations of a new scholarship (pp. 163-175). San Francisco: Berrett-Kohler.

Fredrickson, B. L., \& Branigan, C. (2005). Positive emotions broaden the scope of attention and thought-action repertoires. Cognition E Emotion, 19(3), 313-332.

George, G. (2005). Slack resources and the performance of privately held firms. Academy of Management Journal, 48(4), 661-676.

Gick, M. L., \& Holyoak, K. J. (1983). Schema induction and analogical transfer. Cognitive Psychology, 15(1), 1-38.

Gilbert, B. A., McDougall, P. P., \& Audretsch, D. B. (2006). New venture growth: A review and extension. Journal of Management, 32(6), 926-950.

Gimeno, J., Folta, T. B., Cooper, A. C., \& Woo, C. Y. (1997). Survival of the fittest? Entrepreneurial human capital and the persistence of underperforming firms. Administrative Science Quarterly, 42, 750-783.

Ginsberg, A. (1988). Measuring and modelling changes in strategy: Theoretical foundations and empirical directions. Strategic Management Journal, 9(6), $559-575$.

Gioia, D. A., \& Chittipeddi, K. (1991). Sensemaking and sensegiving in strategic change initiation. Strategic Management Journal, 12(6), 433-448.

Green, S. G., Welsh, M. A., \& Dehler, G. E. (2003). Advocacy, performance, and threshold influences on decisions to terminate new product development. Academy of Management Journal, 46(4), 419-434.

Grégoire, D. A., Barr, P. S., \& Shepherd, D. A. (2010). Cognitive processes of opportunity recognition: The role of structural alignment. Organization Science, 21(2), 413-431.

Grégoire, D. A., \& Shepherd, D. A. (2012). Technology-market combinations and the identification of entrepreneurial opportunities: An investigation of the opportunity-individual nexus. Academy of Management Journal, 55(4), $753-785$.

Hayek, F. A. (1945). The use of knowledge in society. The American Economic Review, 519-530.

Haynie, J. M., \& Shepherd, D. (2011). Toward a theory of discontinuous career transition: Investigating career transitions necessitated by traumatic life events. Journal of Applied Psychology, 96(3), 501-524.

Haynie, J. M., Shepherd, D. A., Mosakowski, E., \& Earley, P. C. (2010). A situated metacognitive model of the entrepreneurial mindset. Journal of Business Venturing, 25(2), 217-229. 
Haynie, J. M., Shepherd, D. A., \& Patzelt, H. (2012). Cognitive adaptability and an entrepreneurial task: The role of metacognitive ability and feedback. Entrepreneurship Theory and Practice, 36(2), 237-265.

Heck, R. K., \& Trent, E. S. (1999). The prevalence of family business from a household sample. Family Business Review, 12(3), 209-219.

Hisrich, R. D., \& Cahill, D. J. (1995). Buried at the crossroads at midnight with an oak stake through its heart: An entrepreneurial replication of Ross and Staw's extended temporal escalation model. Family Business Review, 8(1), 41-54.

Hoang, H., \& Antoncic, B. (2003). Network-based research in entrepreneurship: A critical review. Journal of Business Venturing, 18(2), 165-187.

Hoang, H., \& Rothaermel, F. T. (2005). The effect of general and partner-specific alliance experience on joint R\&D project performance. Academy of Management Journal, 48(2), 332-345.

Hobfoll, S. E. (2001). The influence of culture, community, and the nested-self in the stress process: Advancing conservation of resources theory. Applied Psychology, 50(3), 337-421.

Hobfoll, S. E., \& Lilly, R. S. (1993). Resource conservation as a strategy for community psychology. Journal of Community Psychology, 21(2), 128-148.

Hoetker, G., \& Agarwal, R. (2007). Death hurts, but it isn't fatal: The postexit diffusion of knowledge created by innovative companies. Academy of Management Journal, 50(2), 446-467.

Hogan, N. S., Greenfield, D. B., \& Schmidt, L. A. (2001). Development and validation of the Hogan Grief Reaction Checklist. Death Studies, 25(1), 1-32.

Hmieleski, K. M., \& Baron, R. A. (2009). Entrepreneurs' optimism and new venture performance: A social cognitive perspective. Academy of Management Journal, 52(3), 473-488.

Ireland, R. D., \& Miller, C. C. (2004). Decision-making and firm success. The Academy of Management Executive, 18(4), 8-12.

Isen, A. M., Daubman, K. A., \& Nowicki, G. P. (1987). Positive affect facilitates creative problem solving. Journal of Personality and Social Psychology, 52(6), 1122-1131.

Jack, S. L. (2005). The role, use and activation of strong and weak network ties: A qualitative analysis. Journal of Management Studies, 42(6), 1233-1253.

Kahneman, D., \& Tversky, A. (1979). Prospect theory: An analysis of decision under risk. Econometrica: Journal of the Econometric Society, 47(2), 263-291.

Kelley, D. J., Peters, L., \& O’Connor, G. C. (2009). Intra-organizational networking for innovation-based corporate entrepreneurship. Journal of Business Venturing, 24(3), 221-235.

Keltner, D., Ellsworth, P. C., \& Edwards, K. (1993). Beyond simple pessimism: Effects of sadness and anger on social perception. Journal of Personality and Social Psychology, 64(5), 740-752.

Kets de Vries, M. F. (1993). The dynamics of family controlled firms: The good and the bad news. Organizational Dynamics, 21(3), 59-71. 
Kiesler, S., \& Sproull, L. (1982). Managerial response to changing environments: Perspectives on problem sensing from social cognition. Administrative Science Quarterly, 27(4), 548-570.

Kilduff, M., Angelmar, R., \& Mehra, A. (2000). Top management team diversity and firm performance: Examining the role of cognitions. Organization Science, 11(1), 21-34.

Knight, J. (1992). Institutions and social conflict. Cambridge: Cambridge University Press.

Knott, A. M., \& Posen, H. E. (2005). Is failure good? Strategic Management Journal, 26(7), 617-641.

Krueger, N. F., \& Brazeal, D. V. (1994). Entrepreneurial potential and potential entrepreneurs. Entrepreneurship Theory and Practice, 18, 91-91.

Landier, A. (2004). Entrepreneurship and the stigma of failure. Paper presented at the MIT Finance, Development and Macro Workshops.

Langer, E. J. (1989). Mindfulness. Reading, MA: Addison-Wesley/Addison Wesley Longman.

Langer, E. J., \& Moldoveanu, M. (2000). The construct of mindfulness. Journal of Social Issues, 56(1), 1-9.

Lee, S. H., Peng, M. W., \& Barney, J. B. (2007). Bankruptcy law and entrepreneurship development: A real options perspective. Academy of Management Review, 32(1), 257-272.

Lee, S. H., Yamakawa, Y., Peng, M. W., \& Barney, J. B. (2011). How do bankruptcy laws affect entrepreneurship development around the world? Journal of Business Venturing, 26(5), 505-520.

Lewis, H. B. (1971). Shame and guilt in neurosis. Psychoanalytic Review, 58(3), $419-438$.

Lüscher, L. S., \& Lewis, M. W. (2008). Organizational change and managerial sensemaking: Working through paradox. Academy of Management Journal, $51(2), 221-240$.

Maidique, M. A., \& Zirger, B. J. (1985). The new product learning cycle. Research Policy, 14(6), 299-313.

Maitlis, S. (2005). The social processes of organizational sensemaking. Academy of Management Journal, 48(1), 21-49.

March, J. G., \& Shapira, Z. (1987). Managerial perspectives on risk and risk taking. Management Science, 33(11), 1404-1418.

Mason, C. M., \& Harrison, R. T. (2006). After the exit: Acquisitions, entrepreneurial recycling and regional economic development. Regional Studies, 40(1), 55-73.

Masters, J. C., Barden, R. C., \& Ford, M. E. (1979). Affective states, expressive behavior, and learning in children. Journal of Personality and Social Psychology, 37(3), 380-390. 
McGrath, R. G. (1995). Advantage from adversity: Learning from disappointment in internal corporate ventures. Journal of Business Venturing, 10(2), 121-142.

McGrath, R. G. (1999). Falling forward: Real options reasoning and entrepreneurial failure. Academy of Management Review, 24(1), 13-30.

McGrath, R. G. (2001). Exploratory learning, innovative capacity, and managerial oversight. Academy of Management Journal, 44(1), 118-131.

McGrath, R. G., \& Keil, T. (2007). The value captor's process: Getting the most out of your new business ventures. Harvard Business Review, 85(5), 128-136.

McGrath, R. G., \& Nerkar, A. (2004). Real options reasoning and a new look at the R\&D investment strategies of pharmaceutical firms. Strategic Management Journal, 25(1), 1-21.

McGrath, R. G., Tsai, M. H., Venkataraman, S., \& MacMillan, I. C. (1996). Innovation, competitive advantage and rent: A model and test. Management Science, 42(3), 389-403.

McMullen, J. S., \& Shepherd, D. A. (2006). Entrepreneurial action and the role of uncertainty in the theory of the entrepreneur. Academy of Management Review, 31(1), 132-152.

Meyer, J. P., Stanley, D. J., Herscovitch, L., \& Topolnytsky, L. (2002). Affective, continuance, and normative commitment to the organization: A meta-analysis of antecedents, correlates, and consequences. Journal of Vocational Behavior, $61(1), 20-52$.

Meyer, M. W., \& Zucker, L. G. (1989). Permanently failing organizations. Thousand Oaks, CA: Sage Publications, Inc.

Mitchell, R., Mitchell, J., \& Smith, J. (2004). Failing to succeed: New venture failure as a moderator of startup experience and startup expertise. In W. D. Bygrave (Ed.), Frontiers of entrepreneurship research. Wesley, MA: Babson College.

Morrison, E. W. (2002). Newcomers' relationships: The role of social network ties during socialization. Academy of Management Journal, 45(6), 1149-1160.

Neff, K. D. (2009). The role of self-compassion in development: A healthier way to relate to oneself. Human Development, 52(4), 211-214.

Neimeyer, R. A. (2006). Complicated grief and the reconstruction of meaning: Conceptual and empirical contributions to a cognitive-constructivist model. Clinical Psychology: Science and Practice, 13(2), 141-145.

Niedenthal, P. M., Tangney, J. P., \& Gavanski, I. (1994). “If only I weren't” versus "If only I hadn't": Distinguishing shame and guilt in conterfactual thinking. Journal of Personality and Social Psychology, 67(4), 585-595.

Nolen-Hoeksema, S. (1998). The other end of the continuum: The costs of rumination. Psychological Inquiry, 9(3), 216-219.

Nolen-Hoeksema, S., \& Davis, C. G. (1999). "Thanks for sharing that": Ruminators and their social support networks. Journal of Personality and Social Psychology, 77(4), 801-814. 
Ocasio, W. (1997). Towards an attention-based view of the firm. Strategic Management Journal, 18(Special), 187-206.

O'Reilly, C. A., \& Chatman, J. (1986). Organizational commitment and psychological attachment: The effects of compliance, identification, and internalization on prosocial behavior. Journal of Applied Psychology, 71(3), 492-499.

Pachankis, J. E. (2007). The psychological implications of concealing a stigma: A cognitive-affective-behavioral model. Psychological Bulletin, 133(2), 328-345.

Park, C. L. (2010). Making sense of the meaning literature: An integrative review of meaning making and its effects on adjustment to stressful life events. Psychological Bulletin, 136(2), 257-301.

Peng, M. W., \& Shenkar, O. (2002). Joint venture dissolution as corporate divorce. Academy of Management Executive, 16(2), 92-105.

Petroski, H. (1985). To engineer is human: The role of failure in successful design. New York: St. Martin's Press.

Politis, D., \& Gabrielsson, J. (2009). Entrepreneurs' attitudes towards failure. International Journal of Entrepreneurial Behaviour \& Research, 15(4), 364-383.

Popper, K. R. (1959). The logic of scientific discovery. London: Hutchinson.

Probst, G., \& Raisch, S. (2005). Organizational crisis: The logic of failure. The Academy of Management Executive, 19(1), 90-105.

Rank, J., \& Frese, M. (2008). The impact of emotions, moods and other affectrelated variables on creativity, innovation and initiative. In N. Ashkanasy \& C. Copper (Eds.), Research companion to emotion in organizations. Cheltenham: Edward Elgar.

Roberts, K., \& Weitzman, M. L. (1981). Funding criteria for research, development, and exploration projects. Econometrica, 49(5), 1261-1288.

Savickas, M. L. (2002). Career construction: A developmental theory of vocational behavior. In D. Brown Associates (Ed.), Career choice and development (4th edition) (pp. 149-205). San Francisco, CA: Jossey-Bass.

Schwarz, N., Bless, H., \& Bohner, G. (1991). Mood and persuasion: Affective states influence the processing of persuasive communications. Advances in Experimental Social Psychology, 24, 161-199.

Semadeni, M., Cannella Jr., A. A., Fraser, D. R., \& Lee, D. S. (2008). Fight or flight: Managing stigma in executive careers. Strategic Management Journal, $29(5), 557-567$.

Shane, S. (2009). Why encouraging more people to become entrepreneurs is bad public policy. Small Business Economics, 33(2), 141-149.

Shepherd, D. A. (2003). Learning from business failure: Propositions of grief recovery for the self-employed. Academy of Management Review, 28(2), 318-328.

Shepherd, D. A. (2009). Grief recovery from the loss of a family business: A multiand meso-level theory. Journal of Business Venturing, 24(1), 81-97. 
Shepherd, D. A., \& Cardon, M. S. (2009). Negative emotional reactions to project failure and the self-compassion to learn from the experience. Journal of Management Studies, 46(6), 923-949.

Shepherd, D. A., Covin, J. G., \& Kuratko, D. F. (2009). Project failure from corporate entrepreneurship: Managing the grief process. Journal of Business Venturing, 24(6), 588-600.

Shepherd, D. A., Douglas, E. J., \& Shanley, M. (2000). New venture survival: Ignorance, external shocks, and risk reduction strategies. Journal of Business Venturing, 15(5), 393-410.

Shepherd, D. A., \& Haynie, J. M. (2009a). Birds of a feather don't always flock together: Identity management in entrepreneurship. Journal of Business Venturing, 24(4), 316-337.

Shepherd, D. A., \& Haynie, J. M. (2009b). Family business, identity conflict, and an expedited entrepreneurial process: A process of resolving identity conflict. Entrepreneurship Theory and Practice, 33(6), 1245-1264.

Shepherd, D. A., \& Haynie, J. M. (2011). Venture failure, stigma, and impression management: A self-verification, self-determination view. Strategic Entrepreneurship Journal, 5(2), 178-197.

Shepherd, D. A., Haynie, J. M., \& Patzelt, H. (2012). Project failures arising from corporate entrepreneurship: Impact of multiple project failures on employees' accumulated emotions, learning, and motivation. Journal of Product Innovation Management, 30(5), 880-895.

Shepherd, D. A., McMullen, J. S., \& Ocasio, W. (2017). Is that an opportunity? An attention model of top managers' opportunity beliefs for strategic action. Strategic Management Journal.

Shepherd, D. A., \& Patzelt, H. (2015). Harsh evaluations of entrepreneurs who fail: The role of sexual orientation, use of environmentally friendly technologies, and observers' perspective taking. Journal of Management Studies, 52(2), 253-284.

Shepherd, D. A., Patzelt, H., Williams, T. A., \& Warnecke, D. (2014). How does project termination impact project team members? Rapid termination, 'creeping death', and learning from failure. Journal of Management Studies, 51(4), 513-546.

Shepherd, D. A., Patzelt, H., \& Wolfe, M. (2011). Moving forward from project failure: Negative emotions, affective commitment, and learning from the experience. Academy of Management Journal, 54(6), 1229-1259.

Shepherd, D. A., Wiklund, J., \& Haynie, J. M. (2009). Moving forward: Balancing the financial and emotional costs of business failure. Journal of Business Venturing, 24(2), 134-148.

Shepherd, D. A., \& Williams, T. (2017). Hitting rock bottom after job loss: Bouncing back to create a new positive work identity. Academy of Management Review. Forthcoming. 
Shepherd, D. A., \& Suddaby, R. (2017). Theory building: A review and integration. Journal of Management. doi:10.1177/0149206316647102.

Singh, S., Corner, P., \& Pavlovich, K. (2007). Coping with entrepreneurial failure. Journal of Management \& Organization, 13(4), 331-344.

Sitkin, S. B. (1992). Learning through failure: The strategy of small losses. Research in Organizational Behavior, 14, 231-266.

Smircich, L., \& Morgan, G. (1982). Leadership: The management of meaning. Journal of Applied Behavioral Science, 18(3), 257-273.

Smith, W. K., \& Lewis, M. W. (2011). Toward a theory of paradox: A dynamic equilibrium model of organizing. Academy of Management Review, 36(2), 381-403.

Spreitzer, G., Sutcliffe, K., Dutton, J., Sonenshein, S., \& Grant, A. M. (2005). A socially embedded model of thriving at work. Organization Science, 16(5), 537-549.

Stam, W., \& Elfring, T. (2008). Entrepreneurial orientation and new venture performance: The moderating role of intra-and extraindustry social capital. Academy of Management Journal, 51(1), 97-111.

Stroebe, M. S., \& Schut, H. (2001). Meaning making in the dual process model of coping with bereavement. In R. A. Neimeyer (Ed.), Meaning reconstruction \& the experience of loss (pp. 55-73). Washington, DC: American Psychological Association.

Sutton, R. I., \& Callahan, A. L. (1987). The stigma of bankruptcy: Spoiled organizational image and its management. Academy of Management Journal, 30(3), $405-436$.

Swaminathan, A. (1996). Environmental conditions at founding and organizational mortality: A trial-by-fire model. The Academy of Management Journal, 39(5), 1350-1377.

Tangney, J. P. (1989). The test of self-conscious affect. Fairfax, VA: George Mason University Press.

Tangney, J. P. (1991). Moral affect: The good, the bad, and the ugly. Journal of Personality and Social Psychology, 61(4), 598-607.

Tangney, J. P. (1993). Shame and guilt. In C. G. Costello (Ed.), Symptoms of depression (pp. 161-180). Oxford: John Wiley \& Sons.

Tucker, A. L., \& Edmondson, A. C. (2003). Why hospitals don't learn from failures: Organizational and psychological dynamics that inhibit system change. California Management Review, 45(2), 55-72.

Ucbasaran, D., Shepherd, D. A., Lockett, A., \& Lyon, S. J. (2013). Life after business failure: The process and consequences of business failure for entrepreneurs. Journal of Management, 39(1), 163-202.

Ucbasaran, D., Westhead, P., \& Wright, M. (2009). The extent and nature of opportunity identification by experienced entrepreneurs. Journal of Business Venturing, 24(2), 99-115. 
Ucbasaran, D., Westhead, P., Wright, M., \& Flores, M. (2010). The nature of entrepreneurial experience, business failure and comparative optimism. Journal of Business Venturing, 25(6), 541-555.

Van Witteloostuijn, A. (1998). Bridging behavioral and economic theories of decline: Organizational inertia, strategic competition, and chronic failure. Management Science, 44(4), 501-519.

Weick, K. E. (1990). The vulnerable system: An analysis of the Tenerife air disaster. Journal of Management, 16(3), 571-593.

Weick, K. E. (1995). Sensemaking in organizations. Thousand Oaks, CA: Sage.

Weick, K. E., \& Sutcliffe, K. M. (2006). Mindfulness and the quality of organizational attention. Organization Science, 17(4), 514-524.

Weick, K. E., Sutcliffe, K. M., \& Obstfeld, D. (2005). Organizing and the process of sensemaking. Organization Science, 16(4), 409-421.

Whyley, C. (1998). Risky business: The personal and financial costs of small business failure. London: Policy Studies Institute.

Wiesenfeld, B. M., Wurthmann, K. A., \& Hambrick, D. C. (2008). The stigmatization and devaluation of elites associated with corporate failures: A process model. Academy of Management Review, 33(1), 231-251.

Wiklund, J., Baker, T., \& Shepherd, D. A. (2010). The age-effect of financial indicators as buffers against the liability of newness. Journal of Business Venturing, $25(4), 423-437$.

Williams, T. A., \& Shepherd, D. A. (2016). Victim entrepreneurs doing well by doing good: Venture creation and well-being in the aftermath of a resource shock. Journal of Business Venturing, 31(4), 365-387.

Zahra, S. A., Jennings, D. F., \& Kuratko, D. F. (1999). The antecedents and consequences of firm-level entrepreneurship: The state of the field. Entrepreneurship: Theory and Practice, 24(2), 45-45.

Open Access This chapter is distributed under the terms of the Creative Commons Attribution 4.0 International License (http://creativecommons.org/licenses/by/4.0/), which permits use, duplication, adaptation, distribution and reproduction in any medium or format, as long as you give appropriate credit to the original author(s) and the source, provide a link to the Creative Commons license and indicate if changes were made.

The images or other third party material in this chapter are included in the work's Creative Commons license, unless indicated otherwise in the credit line; if such material is not included in the work's Creative Commons license and the respective action is not permitted by statutory regulation, users will need to obtain permission from the license holder to duplicate, adapt or reproduce the material.

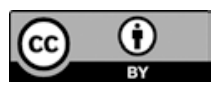

